\title{
Online Opposition and Elections in Malaysia
}

\author{
Rosyidah Muhamad ${ }^{1}$ \\ ${ }^{1}$ School of Social and Economic Development, Universiti Malaysia Terengganu, Malaysia \\ Correspondence: Rosyidah Muhamad, School of Social and Economic Development, Universiti Malaysia \\ Terengganu 21030 Kuala Terengganu, Terengganu, Malaysia. Tel: 60-9-668-3479. E-mail: \\ rosyidah@umt.edu.my
}

Received: November 25, 2014 Accepted: December 29, 2014 Online Published: April 20, 2015

doi:10.5539/ass.v11n10p281 URL: http://dx.doi.org/10.5539/ass.v11n10p281

\begin{abstract}
This paper evaluates the impact of new media on election in Malaysia in the context of equalization and normalization theories in the scholarly literature. Starting in the mid-1990s, major opposition parties in Malaysia have begun to establish an online presence. Malaysia has had its elections in 1999, 2004, 2008 and 2013. Exception in the 2004 General Election, the Malaysian opposition has experienced a consistent upward trend in electoral success over the elections. Most researchers contend the Internet enabled opposition parties to make spectacular electoral gains. What does this the result mean vis-a-vis the equalization and normalization theories debate in the scholarly literature? 15 years of online opposition communication delivered on the back of rising internet penetration over the last four general elections has critically alter the election results. Hence, the equalization thesis' prediction that the Internet holds the potential to give opposition parties equal footing to the ruling parties does explain the situation well in the country.
\end{abstract}

Keywords: general elections, internet, opposition parties

\section{Introduction}

In an article published in early 2012, Larry Diamond identified Malaysia as one of several Asian countries that could form the "coming wave" of democratization. Pointing to high per capita income and Malaysia's good Human Development Index score, Diamond (2012, p. 9) contends that "from the standpoint of modernization theory, Malaysia is [...] ripe for a democratic transition". This is not the first time that political observers have speculated about such a transition in Malaysia. In the 1999, 2008 and 2013 general election, though the ruling BN maintained its majority in the general election, the victory was a narrow one. Other scholars, however, are more skeptical. Abbott (2009), for example, highlights the remarkable resilience of the BN regime and calls for caution about predicting a democratic transition. Similarly, the frequent classification of Malaysia as an "electoral authoritarian" regime (Schedler, 2002; Ufen, 2008) indicates that stability rather than change might be the most likely future prospect for this country which, despite regular elections, has been ruled by the same political coalition since independence.

Despite such diverging assessments, there is near-universal agreement among scholars that the Internet now plays a key role in shaping Malaysian politics. Even tightly control of mass media, the opposition coalition Pakatan Rakyat (PR) able to mobilize supporters in unprecedented numbers. Most scholars argued that the success of the PR was due to its use of the Internet (Ufen, 2008; Rashid, 2009; Abbott, 2011). In the 2008 Malaysia General Election, the use of the internet is believed to be one of the factors that contributed to the unprecedented results of the election (see e.g., Azizuddin, 2009). The opposition alliance - the People's Coalition (Pakatan Rakyat [PR]) gained control of five states, denying the ruling party a two thirds majority in the parliament. Abdullah Ahmad Badawi; former Malaysia Prime Minister, acknowledged, 'It was a serious misjudgment. We thought that newspaper, the print media, the television were important but young people were looking at text message and blogs the effect was a serious misjudgment' (NST, 2008, p. 2).

The combination of a government-controlled mainstream media and a fairly free Internet in Malaysia provides a unique opportunity to test the potential impact of online media on the election result. This paper will base its analysis by measuring the duration of opposition parties' online communications against electoral results in the country's general elections over the last four general elections; 1999, 2004, 2008 and 2013. The impact of new media on the election result will be evaluated in the context of equalization and normalization theories in the 
scholarly literature. The aim was to document the role on online media in Malaysian society in which the opposition parties limited access to the mass media and in turn, the people seek alternative news elsewhere e.g the internet. The study concludes that the highly use of the online media by opposition groups did have impact in the election results.

\section{Scholarly Debate: Equalization and Normalization Theories}

In the scholarly literature on whether new media can contribute to electoral democracy there are two major theoretical views: the equalization theory and the normalization theory (e.g. Bimber \& Davis, 2003; Gibson et al., 2003; Margolis \& Resnick, 2000). Those who advocate the 'equalization' theory argue that the Internet could serve to equalize the electoral playing field among political parties. Such advocates point out that the Internet provides equal information access to the voters. Traditionally parties needed to be very well-funded to create an impact on the voters but the Internet allows for a much cheaper and easier mode of marketing. The several distinctive features compared to traditional media, are low cost, interactive and the campaign message conveyed lack editorial control (Bimber \& Davis, 2003; Kamarack, 1999, p. 14). Thus, 'the small and fringes parties stand a better chance of inter-party competition with the major parties on the Internet than they do in traditional media and thus can reach larger audience'( Margolis et al., 2003, p. 58). This is usually referred to as the equalization theory.

On the other hand, some commentators (e.g. Margolis \& Resnick, 2002; Norris, 2003) have argued that initially the minor parties might dominate, as they have enough resources to hire skillful web designers and develop quality websites to respond to voters' concern. Furthermore, the major parties have the capacity to use TV advertising and also direct mail. This means that the major parties can publish 'their web to a wider offline audience' (Norris, 2003). Then gradually, the major parties would duplicate their present dominance on traditional media onto the web. The dominant political forces would use their pre-existing advantages to reinforce their dominance in new media. This view claims that parties who gain most from new media are those who are already powerful and politically active, while weak parties, who are silent offline, remain quiet online. (Norris, 2003) Major parties have the resources and motivations to build a successful online presence that attracts users, and come to dominate cyberspace (Small, 2008). Instead of creating a more equitable political culture, new media reinforces 'politics as usual'. This is usually called the normalization theory.

What is clear, however, is that the capacity of even the largest parties to engage with internet is limited by available resources. Thus while well-known campaigns, such as the Obama's use of new media provide a model for emulation, the extent to which parties can use new media depends who command the resources to exploit new media. In brief, the parties with more resources both in terms of money and people are more likely to dominate minor parties at election time (Chen, 2010). Research findings in more 'party-centred' countries showed that internet politics in those countries are slightly more resistant to political 'normalization' than in countries where the electoral system is centred on individuals (Small, 2008). It was found that even minor parties managed to keep pace with design sophistication and publicity to remain attractive to users. However a growing number of party-centred countries appear to have been normalized, which challenges the equalization hypothesis above.

The empirical evidence to support either argument is mixed. Many studies in US web campaign support the normalization theory as 'no-change' occurred (Norris, 2003), while studies on other countries such as the UK tend to be inconsistent (e.g. Gibson et al., 2003 \& 2000; Newell, 2001). Some researchers argued it depends on the national and institutional context (e.g. Gibson et al., 2003). Kluver (2004) also notes that political culture plays a significant role in contextualising and limiting the effect of new media on political practice. Thus, there is uncertainty in the scholarly literature. Additionally in terms of methodology the early studies relied on 'feature' analysis of websites. This study aims to go further to look at the presence of websites against electoral results over several elections. It is hoped that an examination and analysis of the use of new media by opposition parties in Malaysia against electoral results over the last $r$ general elections will contribute to this debate.

\section{Traditional Media Vs New Media in Malaysia}

Malaysia is a constitutional monarchy with a federal parliament. The constitution provides a structure for the separation of powers. In practice, however, the concentration of power is in the hands of the executive and frequently the executive dominates the other two branches of government; the legislature and parliament. (e.g., see details in Hwang, 2003; Case, 1996; Crouch, 1996). Malaysia also practices a multi-party system but, in reality it is a single-party system. The dominance of the ruling coalition (Barisan Nasional [BN]), which has ruled for over 53 years, has led to a hegemony of power. The opposition coalition (Pakatan Rakyat [PR]) is only slowly developing and has little access to mass media which mostly is under the control of the BN. 
The mainstream media is a mouthpiece of the BN. Much of the mainstream media in the country are own directly or indirectly by entities linked to the BN. For example, media conglomerate, Media Prima, with the government as a major stake holder, controls stakes in the New Straits Times, Berita Harian, Harian Metro, TV3, $8 \mathrm{TV}$, NTV, TV9 and several more radio stations (Zaharom, 2002). The regulations in the country also hinder the freedom and autonomy of media. Well-known laws such as the Printing Presses and Publication Act 1984, Official Secret Act 1972 and Sedition Act 1948 are used to muzzle the media and prevent the media from performing their function of check and balance on government. The BN leaves these structures in place to ensure the press is used to achieve its political goals (Loh \& Annuar, 1996). In 2010, Reporters without Borders ranked Malaysia 141th in the Press Freedom Index (Reporters without Borders, 2010).

Opposition parties operate in a restricted environment. In addition to very limited access to the mass media, they required permits from the Minister of Home Affairs to produce any party publications. The permit is valid for one year and has to be renewed yearly subject to the ministry's approval (Kim \& Zaharom, 2002). They also need to apply for a police permit 14 days before they are hold open air rallies (Azizuddin, 2008). Therefore, the internet provided the opposition with an additional opportunity for communication and information dissemination to the voters.

Moreover, the Internet penetration has grown dramatically, from 3.7 million users in 2000 to 17.7 million in December 2011 (see Table 1). The number of subscribers of mobile phone was over 36 million (ten million of which have $3 \mathrm{G}$ subscriptions) and almost three million had broadband. More important, in Malaysia, the median age is age of 27 and nearly 2.6 million first-time voters in the 2008 general election. In fact according to Nielsen, in 2010, among the highest users of the Internet in Malaysia is in the age 20-24. They were the person who are used the Internet regularly with average over 22 hours per week spent on the Internet. As the time grows, the Internet also developed with the various types of online exists. In 2008, social media represent a very small group but in 2013, social networking sites such as Twitter and Facebook have become the prime destination of Malaysia's growing internet population. At the end of 2012 Facebook had over thirteen million Malaysian subscribers. 51 percent of Malaysians Internet users have active YouTube profiles and the site accounts for 67 percent of all online videos watched in the country (Navarria, 2013)

Table 1. Internet users in Malaysia

\begin{tabular}{lll}
\hline Year & Internet Users & \% population \\
\hline 2000 & $3,700,000$ & 15.0 \\
2005 & $10,040,000$ & 37.9 \\
2006 & $11,016,000$ & 38.9 \\
2007 & $13,528,200$ & 47.8 \\
2008 & $15,868,000$ & 62.8 \\
2009 & $16,902,600$ & 65.7 \\
2010 & $16,902,600$ & 64.6 \\
2011 & $17,600,000$ & 62.2 \\
2012 & $17,723,000$ & 60.7 \\
2013 & $18,000,000$ & 62.0 \\
\hline
\end{tabular}

Source: Compilation from ITU, World Statistics and MCMC

\section{Opposition Used Internet and Government Reactions}

Generally, Malaysia opposition parties began by using the Internet informally for internal communications and externally via 'mailing list groups' to communicate with the voters. Since 1990s, the opposition parties recognized this technology potential and made use of it, especially in the elections (Rosyidah, 2010). Formal websites were launched in the 1990s but only for information dissemination (see Table 2). The parties used the websites to explain their policies, activities and personalities to the electorate. Gradually, by the late 90s, the way the internet was used in campaigns has ranged from the use of the party websites to the use of blogs particularly among the opposition leaders. Key political figures such as Lim Kit Siang and Anwar Ibrahim launched their blogs, with regular updates and multiple posts daily, attracting huge numbers of visitors. Their blogs have links to the formal political parties' websites. 
In the early 2000s, opposition parties have also used social media to broadcast videos of parliamentary debates on their websites. Most opposition leaders also have their own Facebook accounts, actively use Twitter, YouTube and also SMS by mobile phone. Despite the opposition's wide use of the internet; it made no major impact in the 2004 General Election. Indeed major studies of the 2004 General Election such as Loh (2004) and Marzuki (2004), which saw the BN win spectacularly, did not refer to the Internet at all. It was in the 2008 and 2013 General Elections and after more than 10 years of internet use, that a clear impact could be seen. Indeed, most observers cited the internet as one of the factors that contributed to the victory of the opposition parties.

Table 2. Malaysian political party websites

\begin{tabular}{lll}
\hline $\begin{array}{l}\text { Political party } \\
\text { Ruling Coalition (BN) }\end{array}$ & Website established & URL \\
\hline UMNO & 2001 & http://umno-online.com \\
MCA & 1997 & http://www.mca.org.my \\
MIC & 2000 & http://www.mic.org.my \\
Gerakan & 2000 & http://www.gerakan.org.my \\
Sabah United Party (PBS) & 1997 & http://www.pbs-sabah.org \\
Opposition Coalition (PR) & & \\
PAS* & 1999 & http://www.pas.org.my \\
DAP* & 1996 & http://www.dapmalaysia.org \\
PKR* & 2004 & http://www.keadilanrakyat.com \\
\hline
\end{tabular}

Source: www.archive.org

* Consolidated from interviews with opposition party webmasters and cross-checked with www.archive.org

Although opposition parties are active on the internet, Malaysia has no specific laws to control online political content and a provision of the Communication Multimedia Act 1998 (CMA) explicitly states that nothing in the act "shall be construed as permitting the censorship of the Internet." The MSC Bill of Guarantees also promises no censorship of the internet. However, the extensive powers available to the government under existing laws such as the Sedition Act and the Internal Security Act (ISA) have been used to prosecute online dissent in well-known cases such as the Raja Petra Kamaruddin (RPK) (The Star, 12 September 2008), and Khairul Nizam Abdul Ghani (Singh, 2010) cases.

There are also a number of Malaysian bloggers have faced legal harassment, intimidation, fines and brief periods of detention (Freedom House, 2011). For example, on 13 March 2009 eight bloggers were charged under the CMA for insulting the Sultan of Perak, one of nine Malay rulers. In January 2010, another blogger, Khairul Nizam Abdul Ghani, was accused of insulting the king. He had posted critical comments on his blog concerning the late Sultan of Johor, Sultan Iskandar Ismail. Another blogger, Syed Azidi Syed Aziz, or Kickdefella, was arrested on 17 September 2008, and investigated under the Sedition Act. He was arrested because he appealed online for people to fly the national flag upside down as a sign of dissatisfaction about certain government policies. Wee Meng Chee (known as Namewee) was questioned in August 2007 over a YouTube video that allegedly contained racist remarks. The most controversial blogger, Raja Petra Kamaruddin, was also charged several times by the authorities in relation to his blog, Malaysia Today. He left the country during his trial and a warrant was issued for his arrest. These cases illustrate that the ruling BN has been willing to use the law to silence online dissent especially when bloggers touch on sensitive issues.

Malaysian Internet service providers are subject to the Malaysian Communication and Multimedia Commissions (MCMC) and are required to prevent any improper use of the Internet. In August 2008, the MCMC ordered all major ISPs to block the website Malaysia Today under Sections 263 and 233 of CMA (The Star, 29 August 2009). According to the head of the MCMC, Mohammed Sharil Tarmizi, the website was blocked because "some of the comments on the website were insensitive, bordering on incitement" (Malaysia Kini, 27 August 2008). Following a public outcry, the ban was removed (The Star Online, 11 September 2008).

There have also been many reports that websites of independent online news and oppositional websites have been attacked by a distributed denial of service (DDOS), that is, various systems of attacks on a single system forces the targeted system to shut down, where, for example, a flood of messages to the target system essentially forces it to close. Some suspect that the attacks were carried out by the government while others believe that they were sponsored by the Malaysian security agencies (Freedom House, 2011). In September 2009 and September 
2010, Malaysia Today was attacked by DDOS after RPK released a story on government corruption. The attack indicated that "its instigators were professional for-hire hackers" (Thien, 2011, p. 46). Other websites, including Anwar Ibrahim's blog and Free Malaysia Today, also suffered similar attacks in September 2010 (Thien, 2011).

There are a number of people have faced prosecution and been charged. However, it should also be noted that those who were not charged with serious offences were immediately released and none faced any physical violence. This could suggest that the control of cyberspace is exercised more through threats and warnings than anything else. The threat of prosecution highlights the capacity of authorities to exert pressure for self-censorship in what Lee T. (2005, p. 82) called "auto-regulation", described as "a policy discourse where discipline and control is carried out automatically without the need for direct policing or overt surveillance and supervision." In addition to the threat of prosecution, the government engages in surveillance. For example, in 2007, all prepaid mobile phone users (around 14 million) were required to register as part of a government effort to curb misuse of the mobile phone system and to improve security. It is now easier for authorities to track and access text messages, with the help of domestic ISPs (Freedom House, 2011). In 2010, the Information minister suggested that all bloggers must register but this attracted protest and the idea was dropped (Thien, 2011).

The government introduced measures for monitoring online activities. For example, Home Affairs minister Hishamuddin Hussein Onn announced the formation of "a special unit" to monitor online postings that could touch on sensitive issues and cause political instability. Comprising the police, officers from the attorney-general's office and representatives of the Home Affairs ministry, this special unit was given the task to monitor websites and blogs (The Star Online, 12 September 2008). However, it was unclear how this monitoring effort would be implemented.

Though there are various ways for the government to monitor online activity, it is unnecessary when people start to practise self-censorship. Studies by Rodan (2003), Lee, T (2005) and Gomez (2002) have all noted that control of the Internet has more to do with self-censorship than government censorship. This means the government's approach can be defined as "light touch", in which self-monitoring is prioritised and punitive action is the last resort (Lee, T., 2005). This does not conflict with economic policies and simultaneously allows the government to regulate online political dissent.

\section{Impact of New Media on Electoral Results}

Ever since the Internet was available in Malaysia, the one question that has interested observers over the supply of online political content is the impact it might have on politics, especially during elections. With the rise of blogs in the elections and the emerging significance of social media in the country, the follow up question is whether opposition parties use of new media have been able to affect electoral outcomes in the last five general elections. Malaysia has strong opposition parties, an active civil society and a growing amount of online political content, and the results over the last two general elections hold the evidence that voters are more or less influenced by the new media.

Table 4 shows that there have been significant swings in BN's share of the popular vote from the high of 65.2 per cent in 1995, when the Internet was still very much an 'unknown' in mass communication in the country. After 1995, Table 4 shows the fluctuation in the percentage of votes for BN dropping in 1999 to 56.5 per cent, rising to 63.9 per cent in 2004 and plunging again to 51.4 per cent in 2008. Then in 2013, percentage of votes for BN still falls. The rise and fall in percentages in the election year of 1999 and 2004 do not correlate to the use of new media by opposition parties. Similarly, Table 5 shows that the number of BN seats at federal level changed in tandem with the popular vote. The ruling coalition held on to its politically and psychologically critical two-thirds majority until the 'political tsunami' of 2008. The opposition parties, united under the Pakatan Rakyat (People's Alliance [PR]) banner, captured 82 seats - a big jump from the 20 they won in 2004 and again they captured biggest seats in the 2013 with 89 seats.

Table 3. Percentage of popular votes for Barisan Nasional

\begin{tabular}{ll}
\hline General elections & Percentage of votes \\
\hline 1995 & 65.2 \\
1999 & 56.5 \\
2004 & 63.9 \\
2008 & 51.4 \\
2013 & 47.4
\end{tabular}

Source: Compiled from Election Commission of Malaysia (www.spr.gov.my) 
Table 4. Number of seats in parliament

\begin{tabular}{lll}
\hline General elections & Barisan Nasional & Opposition \\
\hline 1995 & 162 & 30 \\
1999 & 148 & 45 \\
2004 & 199 & 20 \\
2008 & 140 & 82 \\
2013 & 133 & 89 \\
\hline
\end{tabular}

Source: Compiled from Election Commission of Malaysia (www.spr.gov.my)

Exception in 2004, the Malaysian opposition has experienced a consistent upward trend in electoral success over the last three elections. The opposition made gains in the number of seats in Parliament in 1999 winning 45 seats from 30, but then lost half that number in 2004. The biggest gain was in 2013, when the opposition won 89 seats, denying the ruling party a two-thirds majority. The 2013 election also saw the opposition winning almost half of all votes cast, giving Barisan losing its two-third majority in Parliament.

The comparison of electoral results in the country shows that use of new media by opposition parties displays correlation to electoral outcomes. In facing the 1999 general election, Malaysian society started to show signs of revolt against the government, especially after of the dismissal of Anwar. A reform movement arose and since then, dissenting voices have been vibrant. Dozens of websites sprang up immediately after Anwar's arrest, posting the latest news and rumours, as well as links to foreign news sources. The estimated number of websites rose to up to 50 (George, 2006; Zaharom, 2002), a significant number considering that the Internet in Malaysia was still new then. Popular sites such as MalaysiaKini.com, Laman Reformasi, Freeanwar.com, harakahdaily.com and FreeMalaysia.com offered alternative news and information about the crisis, and received a significant number of hits per day (Netto, 2002). Some of these websites were owned by popular webmasters, for example Sabri Zain (Reformasi Diary) and Raja Petra Kamaruddin (Malaysia Today). The first online news portal to emerge before the 1999 general election was Malaysia Kini, founded by Steven Gan and Premesh Chandran, who were joined by journalists concerned about the credibility of the news (Tong, 2004). Malaysia Kini quickly became the most popular news portal in Malaysia and its readership reached half a million hits during its first month of operation (Netto, 2000). The readership continued to achieve high figures after the election, averaging 100,000 hits per day - more than the circulation of the top daily newspapers, The Sun and The Star (Zaharom, 2000).

Not only were civil society agencies active online, but opposition parties also used the net for public outreach, especially during the 1999 general election. For instance, PAS set up its first website in 1999 (details are discussed in Chapter Four below). PAS launched the first Net TV (Harakah web TV) in May 1999 and also turned its weekly newspaper Harakah into an online journal when the government restricted its sale from twice a week to once a fortnight. The new KeADILan party was refused permission to publish any printed material to promote its platform, so it, too, turned to the Internet to reach wider audiences. It should be noted that publishing news online was helpful for opposition parties because it meant that they no longer had to comply with the Printing and Publication Act. However, at this time, the Internet was not as sophisticated as it is today. At the beginning, most of the online platforms disseminated news one-way only. For political parties, the Internet was a way to present information about office holders and candidates, to disseminate press releases and to make public announcements. There was no way for readers to provide feedback or to add any information to what was available. Nonetheless, the combination of the online presence of civil society and opposition parties, the growth of websites, chat rooms, listservs and emails was significant in the lead-up to the election.

As a result, though the BN maintained its two-thirds majority, it was a tough victory. It is evidence that the Internet had become a new space for political activists and opposition voices to disseminate political information and news. Taylor (2004) analysed the 1999 election result and noted that the result was still significant in term of seats won by the opposition parties even though the number of seats won was small. Many of the seats won by the BN were won only narrowly. Moreover, in the Federal Territory of Kuala Lumpur and Selangor, where the Internet had the largest impact, the opposition coalition gained the largest margin.

By the 2004 general election, blogs and independent websites were definitely on the rise and had become important tools for political communication. Many NGOs began to set up their own websites. Examples include the country's pioneer civil rights group's Aliran Online (Aliran.com); Suaram (Suara Rakyat Malaysia, Voice of the Malaysian People), with its Suaram.net to support victims of state oppression; women's advocates 
Tenaganita (www.tenaganita.net); Islamic youth activists ABIM (www.abim.org.my); Muslim women advocates, Sisters in Islam (www.sistersinislam.org.my); and the Malaysian Bar (www.malaysianbar.org.my). The first political bloggers to appear were Jeff Ooi in 2003 and Raja Petra Kamaruddin, the founder of the Malaysia-Today website (Gomez \& Chang, 2010).

Yet, the online presence of so many NGOs and individuals bloggers had no significant impact on the election. Instead, the 2004 election represented an opportunity for the newly-appointed Prime Minister Badawi to obtain a fresh mandate for the BN after 22 years under Mahathir. During this period, the mainstream media played its role in "welcoming" the new prime minister with his nickname, Pak Lah. As noted by Mustafa, the newspapers, specifically The New Straits Times, The Star, Berita Harian and Utusan Malaysia, emphasised "the Pak Lah" factor. Pak Lah was portrayed by the daily newspapers as "clean, non-confrontational, humble, gentle and affable as well as a people friendly leader" (Mustafa, 2005, p. 36). In addition, his slogan "work with me, not for me" was advertised widely in the newspapers; through it, Badawi promoted an image of care and concern for the people, especially those who had felt alienated during Mahathir's rule.

Unlike in 1999, the 2004 general election featured no sensational issue that could be covered by the opposition parties. Instead, most of their energy was spent on countering the image campaign of Pak Lah. The opposition used the Internet to spread news about Badawi but it was not particularly effective, as there was no controversial issue to be covered. Most news concentrated on Badawi's new transformation plan, which included fighting corruption and ensuring more accountability and transparency in the administration (Marzuki, 2004). Such promises gave people hope in a new Badawi administration. Opposition figures like Anwar Ibrahim and Lim Kit Siang used their personal blogs to convey their messages to the public, but these had no major impact during the 2004 general election. As Smeltzer and Lepawsky (2010) show, the alternative media played a minimum role in the 2004 election.

Not long after the BN's overwhelming victory in the 2004 general election, many people lost faith in Abdullah Badawi's leadership. Seen as incompetent, he and his administration soon became the target of widespread criticism. Significantly, his critics included a number of government insiders. Among the popular bloggers who sharply criticised the administration was a former secretary of UMNO, "Sang Kelembai" (Zaharin Mohd Yassin). Datuk Ruhanie Ahmad had been secretary of politics for former Deputy Prime Minister Musa Hitam; and an UMNO MP of Parit Sulong in Johor, wrote his blog under the pseudonym "Kuda Kepang" in order to criticise Badawi's government. Other popular bloggers, including Aisehman and Cuit Sikit, also had previously been on the government's side. They all tended to oppose government policy even though they were in government themselves. Another who lent his voice to the chorus of criticism was former prime minister, Mahathir Mohamed, who wrote his own blog on the website chedet.co.cc. According to Kee and Ahmad et al. (2010), Mahathir's use of his blog to target personality of Badawi constituted 58.8 per cent of his postings and received a high level of response from readers.

It was not only people close to the government who attacked the new prime minister. Ordinary citizens also used blogs to show their dissatisfaction, including Rocky Bru (Ahiruddin Atan), formerly a Malay newspaper journalist, and UMNO media advisor and editor of Berita Harian, Abdul Kadir Jasin - known as the Scribe. Both were critical of the government. Marina Mahathir, daughter of Mahathir, also turned to online writing on the blog, Rating MM. Another important blogger, Raja Petra Kamaruddin (RPK), with his website, Malaysia Today, became famous for his exposure of corruption, abuse of power and the incompetence of the BN party. His blog gained in popularity and eventually attracted the authorities' attention. He criticised not only the government but also the opposition parties. His postings attracted thousands of readers and some of them reproduced his thoughts in other blogs. Most of these people were not necessarily supporters of the opposition parties but were simply frustrated with the BN government and particularly the Badawi administration. It was difficult for Badawi to deal with these bloggers or even to respond to them, as they were people who normally supported the BN. However, as the next election approached, several active bloggers were given a chance by opposition parties to become candidates in the 2008 poll. Among them were Tony Pua, Jeff Ooi, Badrul Hisham Shahrin, Teresa Kok, Nik Nazmi and Hannah Yeoh (Smeltzer, 2008; Beng, 2009).

This period also witnessed the arrival of more independent online news. In addition to Malaysia Kini, other independent news sources such as Nut Graph, The Malaysian Insider, Malaysia Mirror, Free Malaysia Today arose. As a result, during the 2008 general election campaign, Malaysians had easy access to a large amount of free, alternative information produced by professional journalists as well as citizens and amateur journalists (Gomez \& Chang, 2010).

The political web campaign during the 2008 general election period was dominated by opposition groups and 
those who were dissatisfied with the Badawi administration. Though the BN also had a web campaign, it was "miniscule, despite investing in improved websites" (Suffian, 2008, p. 20). The opposition groups focused their web campaigns on highlighting the weaknesses of the BN such as corruption, criminal activities and the prime minister's credibility (Rashid, 2009). They took the opportunities made available by the Internet to discuss debate and disseminate information to ordinary people without any filtering. As many observers have noted, these activities in cyberspace affected the result of the 2008 general election (Ufen, 2008 \& 2009; Weiss, 2008; Abbott, 2009; Azizuddin, 2009; Rashid, 2009).

In 2008 general elections, the opposition parties seriously make used of the online media. In 2008, various types of online media such as YouTube, Facebook and various alternative news online media became as a vehicle for political mobilization. This media provided a host of digital forums for political deliberation as well as numerous number of news on key national issues. For example, the controversial video on the high profile lawyer, V. K. Lingam who was through phone call attempting to influence judicial appointments with a former chief judge (Liow, 2012). The release of Lingam video through the Internet was directly damage the administration of the BN under Abdullah Badawi as he seriously wants to take his administration fight against corruption. Civil society also collaborated with the opposition parties in the 2008 election and without this collaboration those parties would have found it difficult to make such large gains (Lee et al., 2010; Giersdorf \& Croissant, 2011). Both capitalised on public anger with the government through their campaigns on the Internet. Many areas of policy failure, including rising crime rates, consumer-price inflation and government corruption were highlighted on the Internet. Since the major newspaper and television stations were partly owned by the ruling coalition, NGOs and the opposition parties fully utilised the Internet during the campaign period. They highlighted the weaknesses of the government through technologies such as YouTube, blogging, Twitter and mobile phones. Civil society activities provided an alternative source of information to the public in forums such as the online newspaper, Malaysia Kini, thereby enabling them to challenge the authoritarian rule in Malaysia. Political bloggers like Raja Petra Kamaruddin and Jeff Ooi were among the civil society figures who attracted wide readership in their blogs, giving them significant political influence.

The changes of online politic have not gone without unnoticed by the BN. In facing the 2013 general election, the $\mathrm{BN}$ jumped onto the Internet as well as a sign of willingness to change and also to regain support. Many political leaders from BN have also joined the cyberspace community by launching their own blogs, Facebook and Twitter accounts. BN leaders no longer disregard opinions from the online community as most of them did prior to the 2008 election. Most of them now value the power of the Internet. Most Malaysian political frontrunners have joined Facebook, including Najib Razak, the Prime Minister. By April 2013, Najib followers in his Twitter were 1,460,000 the highest followers compared to the opposition PR political frontrunner - Anwar Ibrahim had 267,000, Nik Aziz 94,000 dan Lim Kit Siang 89,000. Similarly to Facebook 'Like' in which Najib Razak still ahead in 'Like' in his facebook - 1,58,000 while the PR leader- Anwar Ibrahim only 80,000. In fact, Najib also announced few months before the 2013 general election that the country would experience its first 'social media election' (Gomez, 2014). In fact, the party also allocate huge budget for election advertising especially for online advertising especially in projected a singular branding with the single image of Najib as the icon leader (Gomez, 2014). The government also employs a number of 'cyber troopers' or Internet users paid to generate content, rebut criticism and also attack the opposition.

On the other side, the opposition PR also double their effort in combating the BN in using the Internet particularly the social media. DAP as one of the three major parties in PR had created a position in the party to oversee social media publicity for various campaigns. For example, the party manage to collect fund amount RM130,00 in only one campaign (Singh, 2013). In fact according to Yeo Bee Yin, - one of DAP's campaign strategies that the social media really benefited for them due its features of two ways communication and they have very strong online fans and these people were those who spread the party's message (Singh, 2013). Like in the previous election, NGOs also playing its role in supporting the PR. The PR and grassroots organizations once again using the social media, organized Bersih 2.0 in 2011 follow up the 2007 Bersih rally. In reporting the event, the social media became essential tool for protestors to share the event through YouTube, Facebook and Twitter in response to the news report about the event in traditional media. Moreover, the opposition PR launched a campaign by asking citizens to share video or picture through social media during the polls if any sign of fraudulent activity. Since then many photos and videos including 'suspicious ballot boxes dropped by an helicopter on a football pitch and evidence of all other kinds of frauds have flooded in the Internet' (Navarria, 2014, p. 3) and these stimulate for debates.

If the use of new media by opposition parties has impacted the electoral results in a significant way to contribute to electoral change, what does it say of the equalisation and normalisation theories in the scholarly literature? 


\section{Conclusion: Heading towards Equalization in Malaysia}

The findings of this paper show that the equalisation theories present a neat fit as the most useful and accurate explanation of the case of Malaysia. The equalization thesis explains the outcome in the three general elections in Malaysia as the opposition parties managed to secure more seats. Hence when looking to the three elections exception 2004, the results of the elections is consistent and overall the results are conclusive. Therefore this finding gives some credence for the equalization theory as a better explanatory fit and useful as a tool to predict the trends for the next election.

Overall the study demonstrates that equalization thesis explains better the impact of the online opposition parties in Malaysia. The opposition parties have been using online communication since the 1990s, but in the last two elections, their electoral performance aided by new media has resulted in slightly political change in government especially in denied two third majority of seats in Parliament. Instead through the various laws and regulations, the ruling parties continue to make it difficult for the opposition parties to be on equal footing, but the new media enable them. As such this shows the opposition parties' engagement with the Internet may have done to enhance electoral democracy in Malaysia. After more than fifteen years of adopting the Internet; it did significantly alter the electoral fortunes of the opposition parties in the country as the Internet usage and penetration had increased substantially for every year. This is especially correct in term of the emergence of new communication technologies enable the tremendous advances in the production and dissemination of information in which available widely to electorate. In fact, it shows that the traditional mainstream media has lost its monopoly and control over information. Hence, the equalization thesis' prediction that the Internet holds the potential to give opposition parties equal footing to the ruling parties does explain the situation well in the country.

\section{References}

Abbott, J. (2009). Malaysia's transitional moment? Democratic transition theory and the problem of Malaysian exceptionalism. Southeast Asia Research, 17(2), 175-200. http://dx.doi.org/10.5367/000000009788745840

Abbott, J. (2011). Electoral Authoritarianism and the Print Media in Malaysia: Measuring Political Bias and Analyzing Its Cause. Asian Affairs: An American Review, 38(1), 1-38. http://dx.doi.org/10.1080/00927678. 2010.520575

Azizuddin, M. S. M. (2008). Freedom of Speech and Democracy in Malaysia. Asian Journal of Political Science 16(1), 85-104. http://dx.doi.org/10.1080/02185370801962440

Azizuddin, M. S. M. (2009). The public Sphere and Media Politics in Malaysia. Cambridge Scholars Publishing, Newcastle Upon Tyne.

Bimber, B., \& Davis, R. (2003). The Internet in U.S election. New York: Oxford University Press.

Case, W (1996). Elites and regimes in Malaysia: Revisiting a consociation democracy. Monash Asia Institute. Victoria.

Chen, P. (2010). Adoption and use of digital media in election campaigns: Australia, Canada and New Zealand. Public Communication Review, 1, 3-26.

Crouch, H. (1996). Government and society in Malaysia. Cornell University Press. New York

Diamond, L. (2012). China and East Asia; This Coming Wave. Journal of Democracy, 23(1), 5-13. http://dx.doi. org/10.1353/jod.2012.0002

Freedom House. (2010). Freedom of the Press: Asia (Scores and status (1980-2008)). Retrieved November 17, 2010, from http://www.freedomhouse.org/template.cfm?page $=439$

Freedom House. (2011). Freedom House Press Freedom Index 2011: Freedom in the world. Retrieved June 13, 2012, from http://www.freedomhouse.org/report/freedom-world/2011/malaysia

Freedom House. (2012). Freedom on the Net. Retrieved June 13, 2012, from http://www.freedomhouse.org/ report/freedom-net/2012/malaysia

George, C. (2006). Contentious Journalism \& the Internet: Towards Democratic Discourse in Malaysia \& Singapore. University of Washington Press.

Gibson, R. K., Margolis, M., Resnick, D., \& Ward, S. J. (2003). Election Campaigning on the WWW in the USA and UK: A Comparative Analysis. Party Politics, 9, 47-75. http://dx.doi.org/10.1177/135406880391004

Gomez, J. (2002). Internet Politics: Surveillance and Intimidation in Singapore. Singapore: Think Centre

Gomez, J. (2014). Social Media Impact on Malaysia's $13^{\text {th }}$ General Election. Asia Pacific Media Educator, 24(1), 
95-105. http://dx.doi.org/10.1177/1326365X14539213

Gomez, J., \& Chang, H. L. (2010). New Media and General Elections: Online Citizen Journalism in Malaysia and Singapore. Paper presented at the Malaysia and Singapore Workshop: Media, Law, Social Commentary, Politics, The University of Melbourne.

Hwang, I. W. (2003). Personalized politics: The Malaysian state under Mahathir. Institute of Southeast Asian Studies. Singapore.

Kee, C. P., Ahmad, F., \& Mahmud, W. A. W. (2010). Indigenizing framing knowledge from content analysing the weblog frames built on the chedet.com. Malaysian Journal of Communication, 26, 47-61.

Kim, W. L., \& Zaharom, N. (2002). Ownership, control and Malaysian media In P. Thomas, \& Z. Nain (Eds.), Who owns the media: Global trends and local resistances. Southbound Sdn. Bhd. Penang Kluver, Randolph. 2004. "Political Culture and Information Technology in the 2001 Singapore General Election." Political Communication, 21(4), 435-458.

Lee, J. C. H., Huat, W. C., Wong, M., \& Guan, Y. S. (2010). Elections, Repertoires of Contention and Habitus in Four Civil Society Engagements in Malaysia's 2008 General Elections. Social Movement Studies: Journal of Social, Cultural and Political Protest, 9(3), 293-309. http://dx.doi.org/10.1080/14742837.2010.493663

Lee, T. (2005). Internet control and auto regulation in Singapore. Surveillance and Society, 3(1), 74-95.

Loh, K. W. F., \& Annuar, M. K. (1996). The Press in Malaysia in the early 1990s- corporatization, Technological innovation and the Middle Class. In M. Ikmal, \& Zahid (Eds.), Malaysia critical perspective - Essay in Honour of Syed Husin Ali. Emby. Petaling Jaya: PSSM.

Malaysia Kini. (2008, August 27). SKMM sekat akses 'Malaysia Today. Retrieved May 8, 2010, from http://www.malaysiakini.com/news/88715

Margolis, M., \& Resnick, D. (2000). Politics as usual: The Cyberspace "Revolution". Thousand Oaks, CA SAGE.

Margolis, M., Resnick, D., \& Levy, J. (2003). Major Parties Dominates, Minor Parties Struggle US elections and The Internet. In R. Gibson, P. Nixon, \& S. Ward (Eds.), Political Parties and The Internet: Net Gain. London: Routledge.

Marzuki, M. (2004). Malaysia's Election 2004; Spectacular Victory Continuing Tension. Kasarinlan: Philipines Journal of Third World Studies, 19(2), 25-53.

Mustafa, K. A. (2005). Politics and the media in Malaysia. Philippine Journal of Third World Studies, 20(1).

Navarria, G. (2013). Malaysia after The Election: A paradigm Shift? Retrieved November 20, 2014, from https://www.opendemocracy.net/giovanni-navarria/malaysia-after-election-paradigm-shift

Netto, A. (2002). Media freedom in Malaysia. Media Asia, 29(1), 17-24.

New Straits Times. (2008). Internet serve a painful lesson.

Newell, J. L. (2001). Italian Political Parties on the Web. The Harvard International Journal of Press/Politics, 6. http://dx.doi.org/10.1177/108118001129172341

Norris, P. (2003). Preaching to the Converted? Pluralism, Participation and Party Websites. Party Politics, 9(1), 21-45. http://dx.doi.org/10.1177/135406880391003

Rashid, M. A. (2009). 2004 and 2008 General Elections in Malaysia: Towards a Multicultural, Bi-party Political System? Asian Journal of Political Science, 17(2), 173-194. http://dx.doi.org/10.1080/02185370903077469

Reporters without Borders. (2010). Press Freedom Index. Retrieved November 29, 2010, from http://en.rsf.org/press-freedom-index

Rosyidah, M. (2010). Malaysian Political Parties on the Web. Paper presented at the 2010 Australian Political Science Association, September 27-29, 2010. Retrieved December 29, 2010, from http://apsa2010.com.au/full-papers/pdf/APSA2010_0027.pdf

Singh, H. (2013). Decisive Impact on Social Media at GE13. The Malaysian Reserve. Retrieved November 20, 2014, from http://themalaysianreserve.com/main/columns/67-habshub-by-habhajan-singh/3647-decisiveimpact-of-social-media-on-ge13

Singh, S. (2010). Blogger pleads not guilty to insulting Johor royals (Update). The Star. Retrieved November 29, 2010, from http://thestar.com.my/news/story.asp?file=/2010/1/29/nation/20100129170602\&sec=nation 
Small, T. (2008). Equal Access, Unequal Success - Major and Minor Canadian Parties on the net. Party Politics, 14(1), 51-70. http://dx.doi.org/10.1177/1354068807083823

Smeltzer, S., \& Lepawsky, J. (2010). Foregrounding technology over politics? Media framings of federal elections in Malaysia. Area, 42(1), 86-95. http://dx.doi.org/10.1111/j.1475-4762.2009.00915.x

Suffian, I. (2008). Reflection of the 2008 Malaysian General Election: Role of the Internet in Political Communications. London: London School of Economics and Political Sciences.

Taylor, S. I. (2004). Information Technology as a democratizing agent: A case study on the 1999 elections in Malaysia. Doctor of Arts, George mason University, Fairfax.

The Star Online 29 August 2008. Syed Hamid Tells Why Malaysia Today was blocked. Retrieved June 7, 2011, from, htp://thestar.com.my/news/story.asp? file=/2008/8/29/nation/22194389\&sec=nation

The Star Online. (2008). RPK arrested under ISA (Update 4). 2008. The Star. September 12. Retrieved November 29, 2010, http://thestar.com.my/news/story.asp?file=/2008/9/12/nation/20080912135857\&sec $=$ nation

Thien, V. V. (2011). The Struggle for Digital Freedom of Speech. In R. J. Dibert, J. G. Palfrey, \& R. Rahozinski (Eds.), Access Contested Security, Identity, Resistance in Asian Cyberspace (pp. 43-63). The MIT Press. http://dx.doi.org/10.7551/mitpress/9780262016780.003.0003

Tong, Y. S. (2004). Malaykini: Threading a tightrope of political pressure and market factors. In S. Gan, J. Gomez, \& U. Johannen (Eds.), Asian Cyberactivism: Freedom of expression and Media Censorship. Bangkok: Friedrich Naumann Foundation.

Weiss, M. L. (2012). Politics in Cyberspace: New media in Malaysia. Friedrich-Ebert-Stiftung (FES), 1-54.

Zaharom, N. (2000). Globalized theories and national controls; the state, the market and the Malaysian media. In J. Curan, \& M. J. Park (Eds.), De-Westernizing Media Studies (Vol. 1). London \& New York: Routledge.

Zaharom, N. (2002). The Structure of Media Industry: Implication for Democracy. In F. K. W. Loh, \& B. T. Khoo (Eds.), Democracy in Malaysia; discourses and practices. Curzon Press Richmond. Surrey.

\section{Copyrights}

Copyright for this article is retained by the author(s), with first publication rights granted to the journal.

This is an open-access article distributed under the terms and conditions of the Creative Commons Attribution license (http://creativecommons.org/licenses/by/3.0/). 